\title{
DEVELOPMENT OF MODELS OF TECHNOLOGY TRANSFER FOR PUBLIC WORKS
}

\author{
Yuriy Kharytonov' ${ }^{1}$, Serhii Slobodian², Marina Podaienko
}

\begin{abstract}
The aim of the study is to improve the efficiency of technology transfer management in public works by developing a model for the reasonable definition of transfer objects and their components. The subject of the study are models of reasonable definition of technology transfer objects and their components. The basis of the methodology of research are the principles and models of technology transfer, methods and models of the theory of project management, as well as system analysis. The paper shows that for the formation and implementation of public works for various purposes, the goal of using technology transfer processes should be considered the achievement of the highest level of technological development.

Under the conditions of the technological development processes analysis of the individual economic sectors, possible models to achieve different levels of technological development and technical-technological indicators of public works are defined. These include the "gradual" transition model, the "jumps" model, and the "big jump" model. These models are characterized by the following: the model of "gradual" transition assumes that its main feature should be considered a gradual transition from the actual level of technological development to the one following it; for the model of "jumps" the main feature should be considered the possibility of transition to a higher level of technological development bypassing the next in order from the actual level; the "big jump" model differs from the "jumps" one in that a significantly low initial level of technological development immediately reaches the maximum level, which takes place for a certain time. The chosen model of processes to achieve different levels of technological development significantly affects the planning of qualitative and quantitative indicators of public works.

Identification of potential objects of transfer and their components is proposed to solve through the development of classification features of public works and programs, as well as the formation of their information models. The main classification attributes of public works should be considered: organizational, technological, as well as equipment and materials. As the main indicators to ensure effective management decisions in the planning of public works should be used the cost of transfer, as well as the timing of delivery of objects. The conditions for selecting the object of transfer and its components in terms of cost and time for different models of acquisition of the appropriate technological level are defined. A model of technology transfer object distribution and an algorithm for planning public works using technology transfer was developed. The implementation of the research results on a number of public works for the development of municipal heating and water supply systems has proven their effectivenessTaking into account the significant resources needed for public works and programs, the research findings should be considered important for various sectors of the economy.
\end{abstract}

Key words: technology transfer, public works, potential technology transfer objects, models for achieving an appropriate technological level.

JEL Classification: N70, O33

\footnotetext{
Corresponding author:

${ }^{1}$ Admiral Makarov National University of Shipbuilding, Ukraine.

E-mail: kharytonov888@gmail.com

ORCID: https://orcid.org/0000-0002-2425-1758

${ }^{2}$ Admiral Makarov National University of Shipbuilding, Ukraine.

E-mail: slo71nuos@gmail.com

ORCID: https://orcid.org/0000-0002-2439-074X

${ }^{3}$ Admiral Makarov National University of Shipbuilding, Ukraine.

E-mail: Podaienkomarina@gmail.com

ORCID: https://orcid.org/0000-0002-3729-6226
} 


\section{Introduction}

The development of various sectors of modern Ukrainian economy involves the implementation of a number of projects and programs, among which a special position belongs to public works, characterized by the significant amount of resources involved, their social importance, etc. [1-4].

One of the directions of improving the efficiency of the formation and implementation of public works and programs for various purposes should be considered the use of innovative components in them. Innovative components give the project's products competitive qualities and ensure their owners a competitive position in international, regional and industry markets.

Examples of such innovative components are innovative technological platforms Shipbuilding 4.0 (Germany), SmartPort (Netherlands), BIMtechnologies, energy technologies and equipment, advanced management models, etc. [5-15].

The most important and fundamental issues that must be resolved during the period of initiation and planning of infrastructural projects and programs, which will ensure the efficiency of their implementation in the final result, should be the organization of technology transfer processes Particular attention should be paid to the choice of transfer objects (knowledge, experience, industrial property, etc.).

At the same time, it is especially important for public works to determine the models and mechanisms of technology transfer and directly innovative components that can be used in projects and programs, requires separate research.

First of all, this is due to the significant nomenclature of structural and parametric indicators of innovative components and their cost, as well as the need to address issues regarding the effectiveness of their application and so on.

The necessity of tasks' effective solution, which are associated with technology transfer in infrastructural projects ensures the relevance and applied scientific relevance of the research.

\section{Literature analysis and problem statement}

A significant number of publications by domestic and foreign researchers are devoted to modeling the processes of technology transfer and their components in various sectors of economic activity, in the context of the existing specifics inherent in individual states and regions [16-27].

Thus, in (Technology Transfer Desk Reference) there is a review of certain aspects of the current federal Policies, processes, mechanisms and standard model of technology transfer. The publication covers transfer technologies, provides information about federal and non-federal organizations that support such transfers.
Particular attention is paid to methods of resource usage, practical recommendations are given on mar-keting processes in the field of technology transfer.

The structure of the office in the federal laboratory (T2) provides the connection between the laboratory and the technology transfer applicant. The main processes of technology transfer (according to one of the given standard models) are considered: identification of technologies (including intellectual property), technology assessment, identification of potential partners, determination of appropriate transfer technologies, implementation of the transfer and carrying out activities on its completion.

In (Uspenskiy, Kuzmin, Denisenko, Zemtsov, Uspenskiy, Dolgopolova, (2013) the methodological aspects and business model of technology transfer processes, which is used in the Republican Technology Transfer Center of the Republic of Belarus, are considered. The business model of technology transfer processes is divided into four stages: determining the client's potential for technology transfer, identifying technology profiles, finding partners and search tools, negotiating and signing the contract. The main results of the technology transfer business model are considered to be the R\&D contract, the supply contract, the cooperation agreement, the license agreement or the investment agreement.

The purpose of the research (Hanen Kooli-Chaabane, Vincent Boly, Bernard Yannou, 2014) was to adapt the project management methodology for monitoring technology transfer projects. The main goal of the proposed model is to achieve a better understanding of the basic phenomena of technology transfer, so that it can be effectively managed. Particular attention was paid to the detailed description of the stages of the technology transfer project. To fill the gap between the proposed model and the real complexity of the technology transfer process, the research relied on five case studies in which each event or action is tracked and analyzed. The organization and duration of the five stages of the model allow you to control the project's success.

The suggested model serves two main functions: it provides a better understanding of the observed phenomena (with a descriptive and explanatory role) and it improves the efficiency of the monitored impact on the system through better process visibility.

The study (Landry, Amara, Cloutier, Halilem, 2013) expands and integrates elements of the conceptual framework for the creation of the value of knowledge and business. It is shown that knowledge and technology transfer organizations located in Canada are solution centers that bring together knowledge providers and recipients. The results of the research indicate that managers of knowledge and technology transfer organizations can improve their business models and 
increase the value for client companies by improving the level of personality.

The concept of innovative ecosystems has become popular during the last 15 years, which led to a debate on its relevance and conceptual steadiness (Ove Granstrand, Marcus Holgersson, 2020). The purpose of the study has become a review of the definitions of innovation ecosystems and related concepts, on the basis of which the definition of "innovation ecosystem" is proposed. The innovation ecosystem is an assemblage of subjects, activities and artifacts that change, as well as institutions and relations, including mutually supportive and interdependent relations. This definition is combined with the corresponding conceptualizations of innovation systems.

The research was devoted to the evaluation of innovations, especially at the beginning of the development of new products (Marisa Dziallas, Knut Blind, 2019). The study analyzes scientific publications (1980-2015) on innovative indicators. The result of the study should be considered the obtained classification of certain indicators by contextual measurements specific to the company. An analysis of scientific publications found that current publications emphasize qualitative and indirect indicators, but neglect indicators in the early stages of the innovation process. The review identifies 82 unique indicators for evaluating innovation, including 26 indicators for the early stages of technology transfer.

The results of the study cited in (Silva, Feldmann, Spers, Bambini, 2019) analyze and describe the technology transfer processes of Embrapa's agrobiology division. (Empresa Brasileira de Pesquisa Agropecuária - Brazilian Agricultural Research Corporation). The paper examines classical and diffuse models of technology transfer in Brazilian agriculture and shows the role of the government in promoting innovation.

Processes of technology transfer in the oil industry of Libya are shown in (Mohamed, Sapuan, Ahmad, 2010). The article examines the current problematic factors that determine the efficiency of technology transfer. These include the following factors: infrastructural, the factor of state support for technology transfer processes, the factor of training opportunities. The elements of technology transfer support are described: information technologies, research and development, production culture, availability of local subcontractor, etc.

A study is devoted to the analysis of current trends in international technology transfer (Huk, 2013).

The purpose of the work (Obodets, Krasnov, 2012) is to analyze the current state of technology transfer in Ukraine, as well as to identify problems of transfer development and find ways to improve the situation. It is shown that in Ukraine through weak interaction of science and business technology transfer has not found its proper development, and promising scientific developments are often not commercialized. It is noted that the problem for enterprises in need of technology transfer is often a lack of competence in the purchase of technology, and for the developer of the technology - the problem of marketing their own intellectual product.

Based on the analysis of a significant number of scientific publications, (Sazali, Raduan, Suzana, 2012) considers various aspects of the problem of technology transfer as an important catalyst for corporate success and national economic growth. Shows the role of foreign investment and multinational corporations as major sources of technology to improve technological capabilities and competitiveness. The models of technology transfer through the official market channel and through non-market channels are considered.

The purpose of the study (Bozeman, Barry, Heather Rimes, and Jan Youtie, 2015) was to review the literature on technology transfer. This article focuses on an empirical study of technology transfer processes in the United States over the past 15 years. "Out-theDoor", "Market Impact", "Economic Development", "Scientific and Technical Potential", and the like criteria for technology transfer effectiveness are considered.

According to the results of the research presented in (Instytutsiini aspekty mizhnarodnoho transferu znan i tekhnolohii v Ukraini) the main problems in Ukraine in the field of technology transfer were identified: the lack of a geoeconomical strategy, the ineffectiveness of methods of active innovation activities of enterprises, the problem of integration of science and business, etc. All this hinders the country's participation in the international exchange of technology. It is noted that the lack of institutional support for international transfer of knowledge and technology in the economy can be compensated by the involvement of higher education institutions. Universities must play a primary role in building the country's innovation infrastructure and deepening the international transfer of knowledge. Among other things, universities should ensure the training of highquality personnel with higher education to develop and implement innovations in production.

The analysis of publications has shown that currently the issue of technology transfer regarding public works does not solve the needs of the practice of their formation and implementation, which determined the purpose and main objectives of the study.

\section{Objectives of the research}

The aim of the study is to improve the efficiency of technology transfer management in public works by developing a model for the reasonable definition of transfer objects and their components. 
In order to achieve the goal of the study the following tasks were set:

- define processes' models of transition to different technological levels

of the projects' infrastructure components through transfer of technologies;

- develop models for the substantiated determination of the objects of transfer technologies and their components in public works;

- create a model for the dissemination of technology transfer objects;

- design an algorithm for determining the objects of technology transfer and their components in public works.

\section{Research materials and methods}

Identification of the main objects of technology transfer of public works need, above all, to perform research of the subject area of the projects.

The following basic principles, methods and models were used as the basis for the research performed: geoinformation technology, energy management, system analysis, determination of basic structural and parametric characteristics and indicators.

In the methodological aspect, the definition of the main objects of technology transfer of public works needs to perform research into the subject area of the projects.

The basic principles and models of geoinformation technologies were used as the basis for the conducted research, which made it possible to perform these studies in conjunction with the methods and models of system analysis, as well as energy management.

\section{Results of research on technology transfer models}

\section{1. Models of transition processes to different levels of technological development}

Modeling of the processes of technology transfer takes place within the framework of regulatory and legal documents, which are dynamically updated and aimed at ensuring the effective use of scientific, technical and intellectual potential of technology [29-31]. Regulatory documents provide for the solution of issues of property rights, as well as the expansion of international scientific and technical cooperation and regulate the organizational, legal, economic and financial framework of state regulation of activities in the field of technology transfer.

In general terms, the level of technological development of a particular branch of the economy can be characterized by its technological and organizational indicators:

$$
U=\langle P, O\rangle \text {, }
$$

where $U$ - the level of technological development; $P$ - technical and technological indicators; $O_{-}$ organizational indicators.

The purpose of using technology transfer processes should be considered the achievement of the highest level of technological development, i.e. the level existing in the industry (in world practice):

$$
U=\langle P, O\rangle \rightarrow \max \text {. }
$$

The process of technological development of individual economic sectors can be represented as a process of achieving the corresponding $P$ and $O$ indicators (Figure 1).

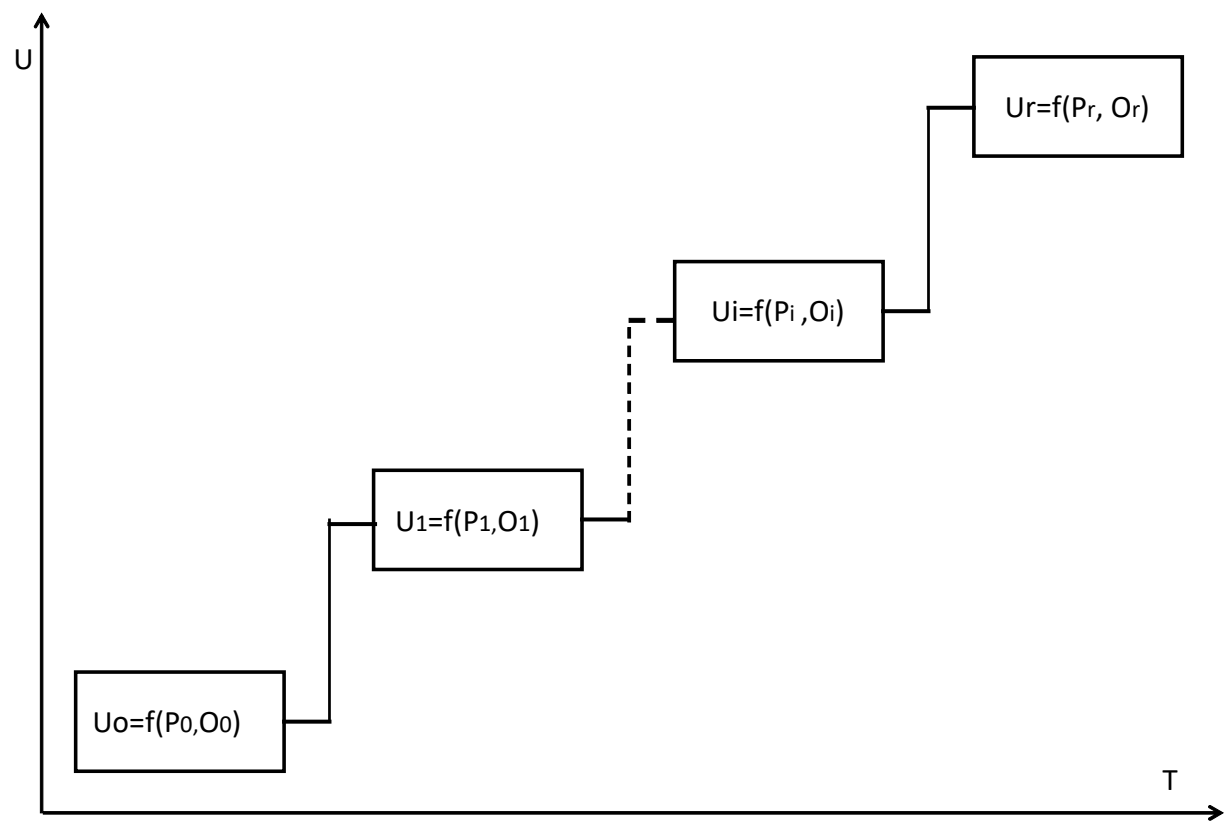

Figure 1. The process of achieving different levels of technological development: $T$ - time 
Thus, taking into account the transfer's effects of technologies, it is possible to define the following models of transition processes which can provide nonlinear character of achievement of separate levels of technological development (Figure 2-4).

The proposed models of processes to achieve different levels of technological development of the industry are characterized by the following. The model of "gradual" transition suggests that its main feature should be considered a gradual shift from the actual level of technological development to the one following it. For the model of "jumps" the main feature should be considered the possibility of moving to a higher level of technological development bypassing the next in order from the actual level. The "big jump" model differs from the "jumps" model in that a significantly low initial level of technological development immediately reaches the maximum level, which takes place for a certain period of time.
Similarly to the accepted models of transition to different levels of technological development it is possible to define models of transition of design and engineering and also organizational indicators (Figure 5-7).

Determined models of the processes of transition to different levels of technological development of the components of public works allow us to take into account the possibility of non-linear nature of the achievement of indicators in the formation of technology transfer processes. The choice of the model of transition to different levels of technological development is based on the conditions of certain criteria.

\subsection{Models for the substantiated definition of technology transfer objects in public works}

The basis for determining the potential objects of transfer and their components is proposed to solve

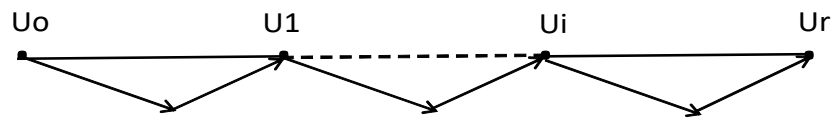

Figure 2. The "gradual" transition model

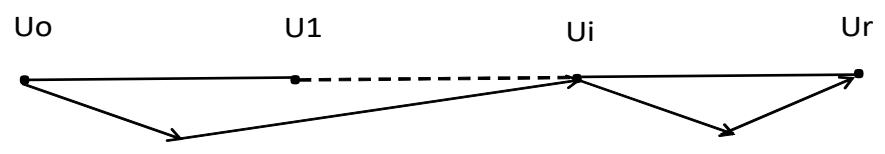

Figure 3. The "jumps" model

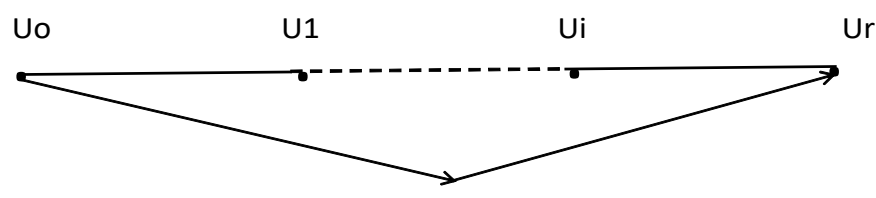

Figure 4. The "big jump" model

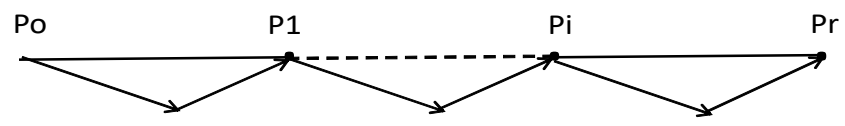

Figure 5. Sequential transition model of indicators

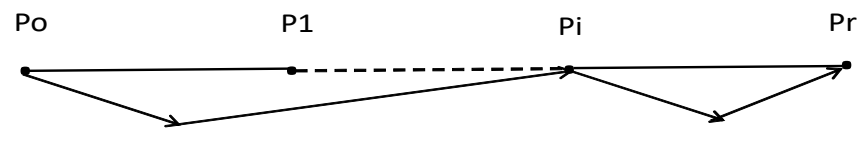

Figure 6. The "jumps" model of indicators

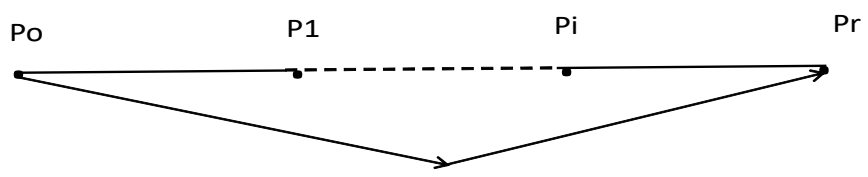

Figure 7. The "big jump" model of indicators 


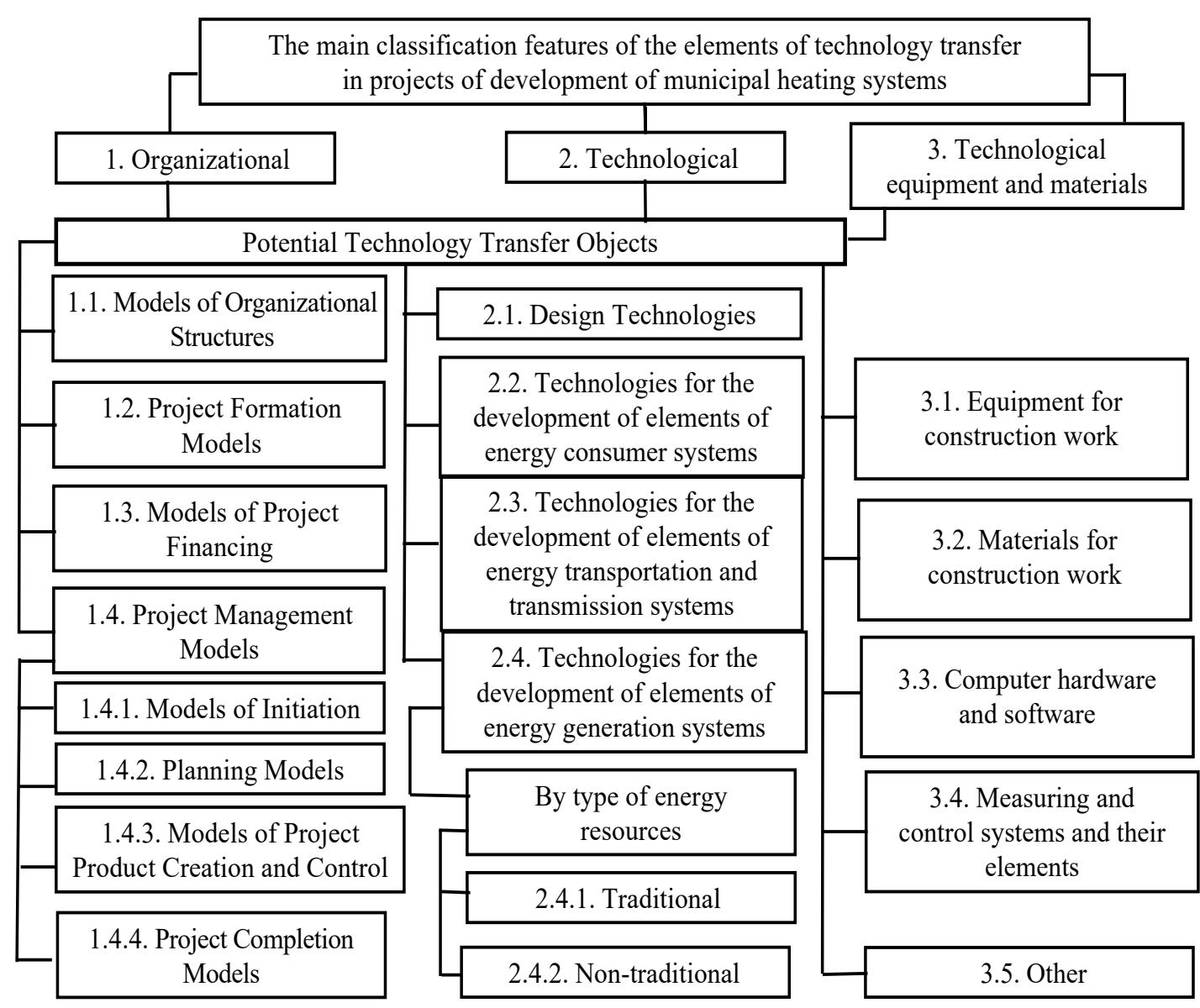

Figure 8. An example of the definition of transfer objects and their components on the basis of classification features of the project

through the development of classification features of projects and programs, as well as the formation of their information models. The main classification attributes of public works can be offered organizational, technological, equipment and materials. An example of the definition of transfer objects and their components on the basis of the classification attributes of the project is shown in Figure 8.

When planning public works, an important stage of work should be considered the creation of matrices of indicators of the levels of design and engineering and organizational development, which allows you to determine the initial technological level of the project: $U_{0}=f\left(P_{0}, O_{0}\right)$,

$$
P_{0}=\left|\begin{array}{l}
P_{1} \\
P_{i} \\
P_{i+1} \\
\cdots \\
\cdots \\
P_{r}
\end{array}\right|, O_{0}=\left|\begin{array}{l}
O_{1} \\
O_{i} \\
O_{i+1} \\
\cdots \\
\cdots \\
O_{r}
\end{array}\right| .
$$

In the conditions $P_{0}=P_{r}$ and $O_{0}=O_{r}$ the technological level of the project corresponds to the high level of $U=U_{\max }$, which exists on the implementation of the planning processes of the project.

Each of the indicators $P$ and $O$ are multiple of design and engineering and organizational indicators, taking into account previously implemented public works for modernization or reconstruction. At the time of determining the real level of technological development, the structure of indicators may have different values, which are inherent in different levels of technological development:

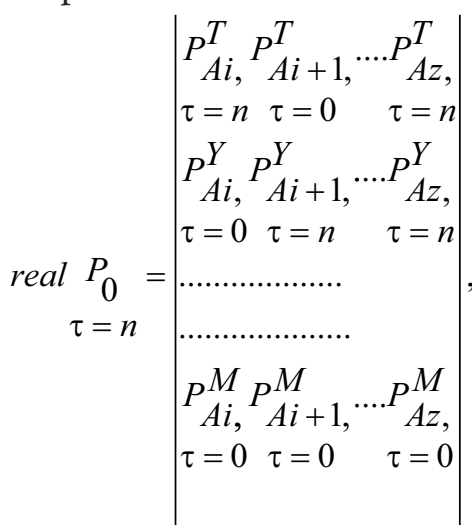




$$
\text { real } O_{0}=\left|\begin{array}{lll}
O_{A i,}^{T} O_{A i+1,}^{T}, \ldots O_{A n}^{T}, \\
\tau=n & \tau=n & \tau=n \\
O_{A i,}^{Y} O_{A i+1}^{Y}, \ldots O_{A n}^{Y} \\
\tau=i & \tau=i & \tau=i \\
\ldots \ldots \ldots \ldots \ldots . . & \\
\ldots \ldots \ldots \ldots \ldots \ldots . . & \\
O_{A i,}^{M} O_{A i+1,}^{M}, \ldots O_{A n}^{M} \\
\tau=1 & \tau=1 & \tau=1
\end{array}\right|,
$$

where real $P_{0}$ - actual level of design and engineering indicators; real $O_{0}-$ valid level of organizational performance.

Potential opportunities to influence the formation and planning of public works by different models and different levels of technological development on certain indicators require design decisions. These decisions can be resolved on the basis of the developed model of reasonable definition of technology transfer objects and their components.

As the main indicators that ensure the adoption of effective in the planning of public works can be used the cost of transfer $-C$ and the terms of delivery of the objects of transfer - $T$ (Figure 9). The cost of the transfer includes the cost of all expenses associated with the procedures of transfer, as well as the direct cost of the object and the components:

$$
C=\sum_{i=1}^{d} c_{i}, T=\sum_{i=1}^{d} t_{i},
$$

where $C$ - includes the cost of all expenses associated with the procedures of transfer, as well as the direct cost of the object and the components; $T$ - transfer object delivery times.

The conditions for selecting the object of transfer by value for different models of acquisition of the appropriate technological level should be considered:

$U_{i}=U_{\max }$ when $C_{\text {add }} \geq C_{r}$ - for the "big jump" model;

$U_{i}=U_{i+1}$ when $C_{\text {add }} \geq C_{i+1} ;$ - for the "gradual transition" model;

$U_{i}=U_{i+m}$ when $C_{a d d} \geq C_{i+m}$; - for the "jumps" model,

where Ui - level of technological development; $U_{i+1}$ - the next level of technological development after the existing one; $U_{i+m}$ - random level of technological development; $C_{\text {add }}$ - the acceptable, under planning conditions, expenses related to transfer procedures and the direct cost of the object and components; $C_{r}-$ the cost of expenses associated with transfer procedures and directly the cost of the object and the components of the transfer at the transition to the highest level; $C_{i+1}$ - the price of the expenses associated with the transfer procedures and the cost of the object itself and the components of the transfer at the transition to the nearest level; $C_{i+m}$ - the value of the expenditures associated with the transfer procedures and directly the price of the object and the components of the transfer at the transition to the random level.

The conditions for selecting the object of transfer by time for different models of reaching the technological level should be considered::

$U_{i}=U_{\max }$ when $T_{a d d} \geq T_{r}$ - for the "big jump" model;

$U_{i}=U_{i+1}$ when $T_{a d d} \geq T_{i+1}$ - for the "gradual transition" model;

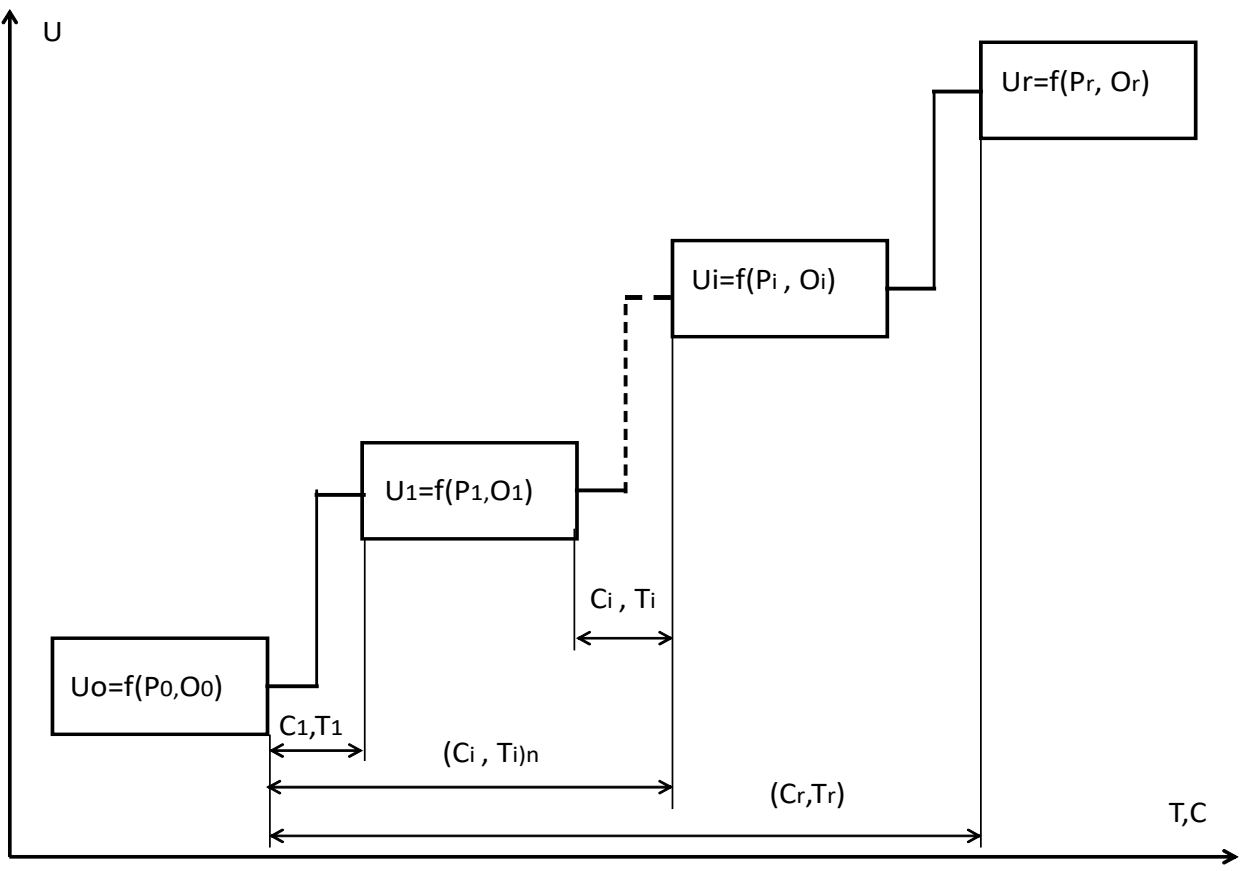

Figure 9. Main indicators of technology transfer of different levels of technological development 
$U_{i}=U_{i+m}$ when $T_{a d d} \geq T_{i+m}$ - for the "jumps" model,

where $T_{\text {add }}$ - acceptable time of transfer objects delivery; $T_{r}$ - acceptable period of transfer objects delivery during the switching to a high technological level; $T_{i+1}$ - allowable delivery time of transfer objects during the transition to the nearest technological level; $T_{i+m}$ - permissible delivery time of transfer objects during the transition to the random technological level.

According to the given conditions for determining the objects of transfer and their components, a list of potential objects of transfer is formed:

\section{$S T=\left\{S T_{i}, E S T_{i}\right\}, S C=\left\{S C_{i}, E S C_{i}\right\}$,}

where $S T$ - multiple objects of technology transfer, selected by time; $S T_{i}$ - the object of technology transfer, which is selected by time; $S C$ - multiple objects of technology transfer, selected by value; $E S T_{i}$ - component of the object of technology transfer, selected by time; $S C_{i}$ - technology transfer object, selected by value; $E S C_{i}$ - component of the technology transfer object, selected by value.

Considering the circumstances that may affect the selection of technology transfer objects, their list is clarified and becomes the subject of planning processes of the components of public works by building an appropriate hierarchy.

\subsection{Model for the dissemination of technology transfer objects}

An important aspect of technology transfer processes should be considered the conditions of their dissemination, which are sufficiently reflected in existing scientific publications.

Given the significant number of typical public works and programs for various industries, it seems possible to propose the following model for the distribution of technology transfer objects (Figure 10). The model does not contradict the existing ones, which are

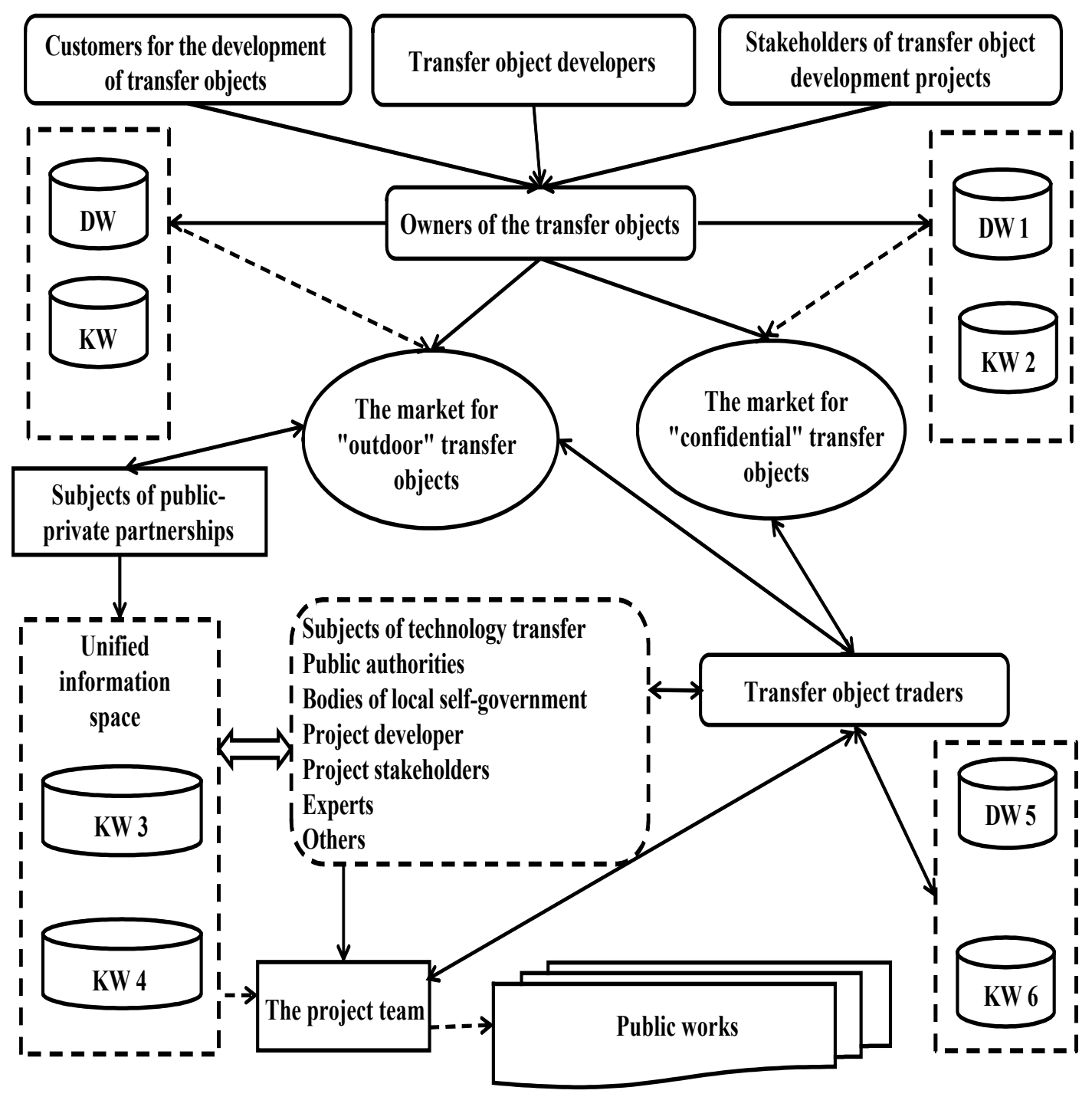

Figure 10. Model for the dissemination of technology transfer objects 
built on the basis of normative documents and complements them.

The developed model is based on the idea of creating a single information space for projects. Due to this the problems of dissemination of technology transfer objects, reducing the total cost of transfer procedures, the introduction of unification of elements of transfer technologies within the framework of public works for their intended purpose, etc. are solved.

Owners of transfer objects in the form of customers and developers of transfer objects, as well as stakeholders of technology transfer object development projects create appropriate information data and knowledge banks.

They are conventionally divided into transfer objects for "outdoor" (DW, KW) and "confidential" (DW 1, KW 1) markets. With traders' participation, owners of transfer objects realize the potential of their innovations.

One of the key issues that should be addressed when transferring technology, especially from abroad, is the issue of providing appropriate resources. The solution to this issue for public works can be proposed through the joint participation of the state and enterprises of various forms of ownership and subordination through the use of a platform of publicprivate partnerships. As a result of such cooperation, a unified information space is formed (DW 3 and KW 4), access to which is used by subjects of technology transfer, public authorities, local governments and others.

Project teams that are responsible for technology transfer planning, with access to relevant knowledge and data warehouses, implement project and program strategies. In terms of technology transfer issues, these include strategies related to achieving the highest possible technological level of the project. Target tasks of technology transfer can be achieved by using the proposed models and certain conditions of reasonable choice of transfer objects and their components.

\subsection{Algorithm for identifying technology transfer objects}

This research allowed us to develop an algorithm for planning public works using technology transfer (Figure 11).

In general terms, the algorithm sequentially defines the processes that ensure the definition of technology transfer objects and their components. It should be noted the processes that precede the creation of the information project model, namely: the definition of the real level of technological development, the formation of a preliminary list of transfer objects and the construction of a hierarchical structure transfer objects.

\section{Discussion of the results of models implementation in the management of public works}

The research results were integrated into existing methods and models of public works management, namely in planning processes. Thus, during the formation of projects for the development of municipal heating systems, using the developed methodology, the objects of technology transfer were identified. These objects were elements of the heat transmission system: heat networks, elements of heat points systems.

The foundation for the development of the potential transfer objects list was the information model, which was developed on the basis of certain structural and parametric indicators of the heat supply systems elements (a fragment of the information model is shown in Figure 12).

According to the results of research, including statistical, technological indicators and the level of technological development of the heat transportation system of the municipality were determined in relation to the current level. Determination of real indicators for pre-insulated pipelines of the existing system and indicators that can be obtained through the transfer of technology has shown the feasibility of their appli-cation in projects based on certain values of $\mathrm{C}$ and $\mathrm{T}$.

Similarly, according to the methodology outlined, such objects of technology transfer as innovative systems of heating the coolant, boiler room equipment and the like were identified.

Testing of the developed models and algorithm allowed to determine their impact on the effectiveness of project management. The practice of using the developed models and algorithm makes it possible to claim an increase in the efficiency of project planning and technology transfer management processes.

The results of the research and their testing in the implementation of numerous public works for various purposes allow us to draw the following conclusions.

\section{Conclusions}

1. The models of "gradual" transition, "jumps" and "big jump" are defined as patterns of transition processes to different levels of technological development of the components of infrastructure projects, and with their help the possibility of non-linear nature of achieving the indicators of technological development is also proved. The chosen model of the processes of transition to different levels of technological development significantly affects the planning of qualitative and quantitative indicators of infrastructure projects.

2. The developed model of reasonable definition of technology transfer objects and their components in public works determines the list of potential transfer 


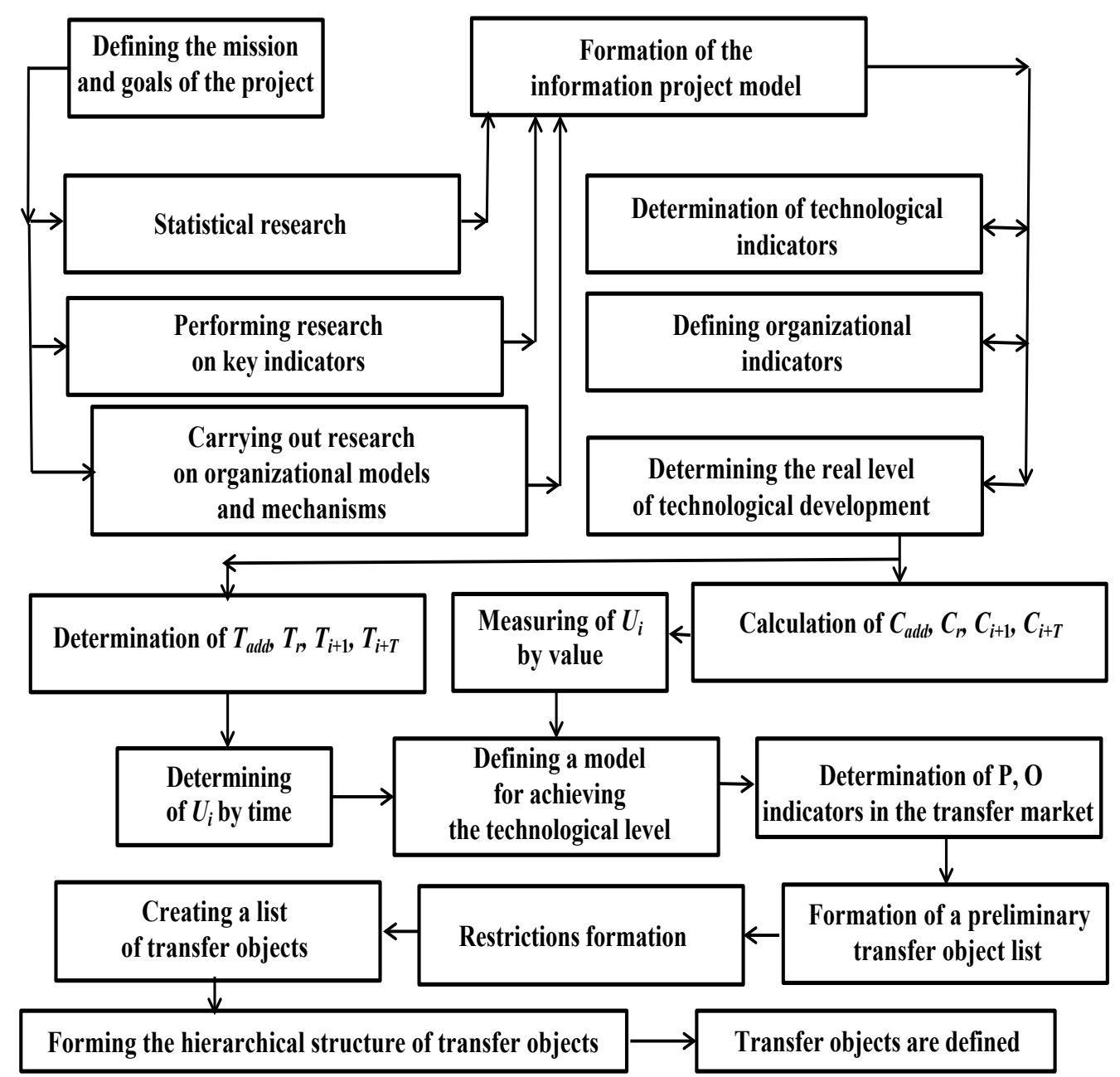

Figure 11. Algorithm for determining the objects of technology transfer and their components in public works

objects and their components in the conditions of determining the cost of transfer and timing of delivery of transfer objects. The reasonable definition model of transfer objects provides a basis for the further process of determining the optimal qualitative and quantitative indicators of transfer objects.

3. The developed model of dissemination of technology transfer objects is based on the creation

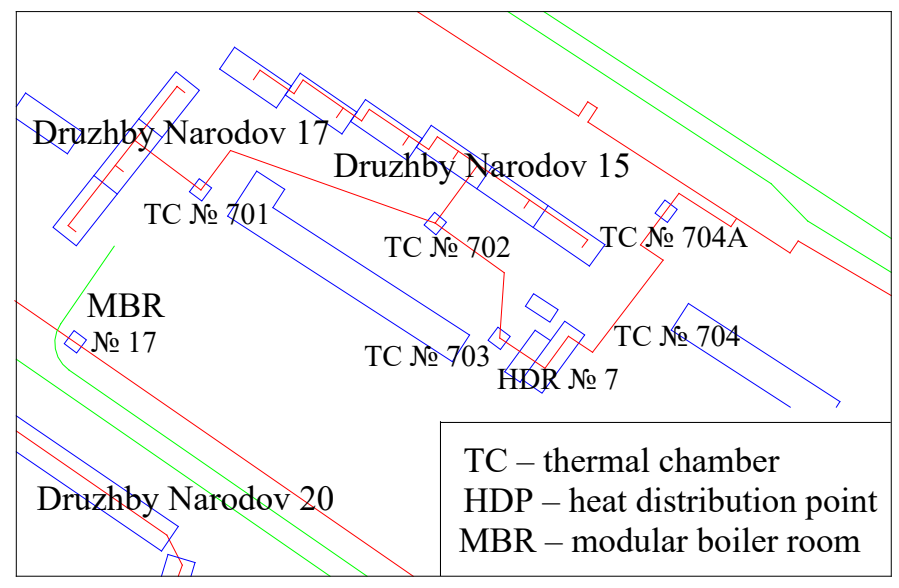

Figure 12. Fragment of the information model in the form of a heat supply system schematic map 
of a unified information space and provides the definition and meaningful content of technology transfer processes from their owners to the stakeholders of public works. Application of the model significantly reduces the time for the formation of public works due to the existing ability to automate the processes of dissemination of technology transfer objects.

4. The algorithm for determining technology transfer objects and their components in public works is the basis for automating technology transfer management processes. The proposed algorithm involves determining the quantitative and qualitative indicators of the objects of transfer, as well as the formation of their hierarchical structure that ensures effective planning of public works in terms of time, cost and quality.

\section{Acknowledgements}

The authors express their gratitude to the staff of the Center for Applied Research in Admiral Makarov National University of Shipbuilding for participation in approbation of research results in the process of implementation of public works of municipal heating and water supply systems development.

\section{References:}

Plan zakhodiv z reformuvannia zaliznychnoho transportu: Rozporiadzhennia Kabinetu Ministriv Ukrainy vid 27.12.2019 № 1411-r.

Reforma infrastruktury. Available at: https://www.kmu.gov.ua/diyalnist/reformi/ekonomichne-zrostannya/ reforma-infrastrukturi

Pro skhvalennia Enerhetychnoi stratehii Ukrainy na period do 2035 roku "Bezpeka, enerhoefektyvnist, konkurentospromozhnist": Rozporiadzhennia Kabinetu Ministriv Ukrainy vid 18.08.2017 № 605-r.

Pro zatverdzhennia planu zakhodiv z realizatsii etapu "Reformuvannia enerhetychnoho sektoru (do 2020 roku)" Enerhetychnoi stratehii Ukrainy na period do 2035 roku "Bezpeka, enerhoefektyvnist, konkurentospromozhnist": Rozporiadzhennia Kabinetu Ministriv Ukrainy vid 06.06.2018 № 497-r.

A vision for the European industry until 2030 / Final report of the Industry 2030 high level industrial roundtable (2019). Publications Office of the EU. Available at: http://op.europa.eu/en/publicationdetail/-/ publication/339d0a1b-bcab-11e9-9d01-01aa75ed71a1

Hribernik, K. (2016). Industry 4.0 in the Maritime Sector, SEA. Tokio, Japan.

Torres, A. (2018). Identifying Challenges and success factors towards Implementing Industry 4.0 technologies in the Shipbuilding Industry. Delft University of Technology.

Case Studies on KETs Marine Applications. Case 1: Advanced Manufacturing Shipbuilding Applications, 2019. Available at: http://ketmaritime.eu/2019/10.

Bernard Ash. Digital shipyard sounds great but what is it? The technologies making it possible. DXC Technology Company. November 2018. 11 p.

OECD Data. Main Science and Technology Indicators. Available at: http://data.oecd.org/rd/ grossdomesticspending-on-r-d.htm

Europe 2020: A strategy for smart, sustainable and inclusive growth. Available at: http://ec.europa.eu

Canada's National Shipbuilding Strategy. Available at: http://www.defenseindustrydaily.com

The National Shipbuilding Research Program. Available at: http://www.nsrp.org

Zhavoronkov, D. (2020). Tsifrovizatsiya Shryodingera: kak v sudprome i na flote (ne)voploschayutsya novyie IT-resheniya. Available at: http://flotprom.ru/2020/ Tehnologii7

Kennedy, S. (2015). "Made in China 2025", Center for Strategic \& InternationalStudies. Available at: http://csis.org/analsys/made-china-2025

Technology Transfer Desk Reference: A Comprehensive Guide to Technology Transfer Sixth Edition October 2013. Available at: http://ictt.basnet.by/Docs/news/2018/04/2018-0409_01/FLC_Technology_Transfer_ Desk_Reference_6th_Edition_2013-10_EN.pdf

Uspenskiy, A., Kuzmin, V., Denisenko, M., Zemtsov, V., Uspenskiy, A., \& Dolgopolova, A. (2013). Respublikanskiy tsentr transfera tehnologiy: 10 let $\mathrm{v}$ natsionalnoy innovatsionnoy sisteme (istoriya razvitiya, struktura, metodologiya, deyatelnost, perspektivyi). Minsk: Kovcheg. ISBN 978-985-7086-20-7

Hanen Kooli-Chaabane, Vincent Boly, Bernard Yannou (2014). Monitoring of technology transfer projects in industrial clusters. Available at: https://www.cairn.info/revue-journal-of-innovation-economics-2014-1page-73.htm

Landry, R., Amara, N., Cloutier, J. S., \& Halilem, N. (2013). Technology Transfer organizations: Services and business models. Technovation, 33. Available at: https://www.academia.edu/10930365/

Ove Granstrand, Marcus Holgersson (2020). Innovation ecosystems: A conceptual review and a new definition. Available at: https://reader.elsevier.com/reader/sd/pii/S0166497218303870?token=9B9C6BFDC5B4E144F0 C3770CDEF8B4C5E1A7C76820726A87940B5B506700295ADB3F0200016D53D6166E24AE0B5366\&origi nRegion=eu-west-1\&originCreation=20210530102033 
Marisa Dziallas, Knut Blind (2019). Innovation indicators throughout the innovation process: An extensive literature analysis. Available at: https://www.researchgate.net/publication/326256032_Innovation_indicators_ throughout theinnovation process An extensive literature analysis

Silva, S. S. D., Feldmann, P. R., Spers, R. G., \& Bambini, M. D. (2019), Analysis of the process of technology transfer in public research institutions: The Embrapa agrobiology case. Innovation \& Management Review, 16(4), 375-390. DOI: https://doi.org/10.1108/INMR-05-2018-0024

Mohamed, A. S., Sapuan, M., \& Ahmad, M. (2010). Modeling technology transfer for petroleum industry in Libya: An overview. Scientific Research and Essay, 5(2), 130-147.

Huk, O. V. (2013). Vitchyznianyi ta zarubizhnyi dosvid derzhavnoho rehuliuvannia u sferi transferu tekhnolohii. Ekonomichnyi prostir, 76, 49-59.

Obodets, R. V., \& Krasnov, O. A. (2012). Transfer tekhnolohii v Ukraini: problematyka, suchasnyi stan ta shliakhy spryiannia yoho rozvytku. Ekonomichnyi visnyk Natsionalnoho hirnychoho universytetu, 2, 40-45.

Sazali, A. W., Raduan, C. R., \& Suzana, I. W. O. (2012). Exploring the Technology Transfer Mechanisms by the Multinational Corporations: A Literature Review. Asia Social Science Journal, 8(3).

Bozeman, Barry, Heather Rimes, and Jan Youtie (2015). The evolving stateof-the-art in technology transfer research: Revisiting the contingent effectiveness model. Research Policy, 44, 34-49.

Instytutsiini aspekty mizhnarodnoho transferu znan i tekhnolohii v Ukraini: realizatsiia kompleksnoho pidkhodu. Available at: http://www.economy.nayka.com.ua/ ?op $=1 \& \mathrm{z}=4583$

Zakon Ukrainy "Pro naukovu i naukovo-tekhnichnu ekspertyzu". Vidomosti Verkhovnoi Rady Ukrainy, 1995 r., № 9, st. 56.

Zakon Ukrainy "Pro derzhavne rehuliuvannia diialnosti u sferi transferu tekhnolohii". Vidomosti Verkhovnoi Rady Ukrainy, 2013 r., № 47, st. 644; 2015 r., № 52, st. 482; 2019 r., № 46, st. 295.

Proiekt zakonu Ukrainy vid 21.01.2021 r. № 4623 "Pro vnesennia zmin do deiakykh zakoniv Ukrainy shchodo stymuliuvannia diialnosti u sferi transferu tekhnolohii". 